23 Baran DT, Teitelbaum SL, Berfield MA, et al. Effects of alcohol ingestion on bone and mineral metabolism in rats. Am f Physiol 1980;238: E507-10.

24 Peng TC, Garner SC, Frye GD, et al. Evidence of a toxic effect of ethanol on bone in rats. Alcoholism 1982;6:96-9.

25 Daniell HW. Osteoporosis of the slender smoker: vertebral compression fractures and loss of metacarpal cortex in relation to postmenopausal smoking and lack of obesity. Arch Intern Med 1976;136:298-304.

26 Kanders B, Dempster DW, Lindsay R. Interaction of calcium nutrition and physical activity on bone mass in young women. Journal of Bone and Mineral Research 1988;3:145-9.

27 Riggs BL, Wahner HW, Melton LJ, Richelson LS, Judd HL, O'Fallon WM
Dietary calcium intake and rate of bone loss in women. $\mathcal{f}$ Clin Inves 1987;80:979-82.

28 Stevenson JC, Whitehead MI, Padwick M, et al. Dietary intake of calcium and postmenopausal bone loss. Br Med f 1988;297:15-7.

29 Goldsmith NF, Johnston JO. Bone mineral: effects of oral contraceptives, pregnancy, and lactation. $\mathcal{F}$ Bone foint Surg 1975;57A:657-68.

30 Christiansen C, Riis BJ, Rodbro P. Prediction of rapid bone loss in postmenopausal women. Lancet 1987; i:1105-8.

(Accepted 6 February 1989)
Pilgrim Hospital, Boston, Lincolnshire PE21 9QS

M Boykett, FFARCS, anaesthetic registrar

Correspondence to: Leicester Royal Infirmary, Leicester LE1 5WW.

BrMed f 1989;298:928

\section{Pulmonary oedema after acute asphyxia in a child}

\author{
M Boykett
}

I report a case of severe pulmonary oedema complicating acute upper airway obstruction.

\section{Case report}

A previously well 8 year old boy was found having choked on a vitamin tablet (Sanatogen Junior, Fisons). He was apnoeic, unresponsive, and cyanosed. During attempts at basic airway resuscitation he coughed up bloodstained mucus before recovering consciousness.

During the next one to two hours, after admission to hospital, he developed tachypnoea, cyanosis, and bilateral lung crepitations. He had radiological signs of florid bilateral pulmonary oedema without cardiomegaly. Oxygen, ampicillin, and hydrocortisone were given, and a rigid bronchoscopy was performed to ensure that there was no residual foreign body. Anaesthesia and bronchoscopy were rendered difficult by a profuse amount of bloodstained froth pouring from the larynx. No foreign body or vomit was found, and he was given intensive care.

With intermittent positive pressure ventilation with $5 \mathrm{~cm} \mathrm{H}_{2} \mathrm{O}$ positive end expiratory pressure and an inspired fractional oxygen concentration of 0.6 his oxygen saturation was initially $87 \cdot 5 \%$ (arterial oxygen tension $9 \cdot 1 \mathrm{kPa}$ ). The arterial $\mathrm{pH}$ of $7 \cdot 18$ reflected mixed metabolic and respiratory acidosis. His general condition, breathing, and arterial blood gas measurements all improved rapidly over the next six to 12 hours. Subsequently, he maintained a normal arterial oxygen tension during spontaneous breathing at 5-10 $\mathrm{cm}$ continuous positive airway pressure and an inspired oxygen fractional concentration of $0 \cdot 25-0 \cdot 30$. Extubation was delayed for two days because of a persistent pink tracheal aspirate and until the radio- logical abnormalities had resolved. Further recovery was complete and unremarkable.

\section{Comment}

An accurate diagnosis proved elusive. Fluid overload and primary left ventricular failure were dismissed as possible causes, and pulmonary aspiration and chemical pneumonitis were considered to be the main differential diagnoses. The history and clinical findings, however, were not characteristic of aspiration. The manufacturer of the tablet and Guy's Hospital's Poisons Unit were consulted, but chemical irritation was excluded as a likely cause.

Similar cases of postobstructive pulmonary oedema have occurred in, for example, laryngospasm, ' croup, and epiglottitis. ${ }^{2}$ Most cases were in children but were less severe than the one reported here, and none was associated with an impacted foreign body. Brown reviewed previous reports and proposed mechanisms by which airway obstruction may cause pulmonary oedema. ${ }^{3}$ These include negative intrathoracic pressure causing transiently low pulmonary interstitial pressure or impaired left ventricular function, or both, and hypoxic postcapillary and venous constriction. Treatment with oxygen alone may be sufficient, but a brief period of tracheal intubation and assisted ventilation may be necessary. Upper airway obstruction occurs frequently, and doctors should be aware of this unfamiliar complication.

I thank Dr M Bexton and Dr A Syed for their help in managing this patient; Dr A Vaizey for permission to report on the patient; Mrs M Chambers and Miss J Norton for typing.

1 Lee KWT, Downes JJ. Pulmonary edema secondary to laryngospasm in children. Anesthesiology 1983;59:347-9.

2 Galvis AG, Stool SE, Bluestone CD. Pulmonary edema following relief of upper airway obstruction. Ann Otol Rhinol Laryngol 1980;89:124-8.

3 Brown RE. Negative pressure pulmonary edema. In: Berry FA, ed. Anesthetic management of difficult and routine pediatric patients. New York: Churchill Livingstone, 1986:168-79.

(Accepted 9 December 1988

\section{Hallucinations after epidural buprenorphine}

\author{
M MacEvilly, C O'Carroll
}

Blackrock Clinic, Blackrock, County Dublin, Republic of Ireland M MacEvilly, FFARCSI, consultant anaesthetist C O'Carroll, SRN, sister, Nightingale unit

Correspondence to: $\mathrm{Dr}$ MacEvilly.

BrMed F 1989;298:928-9
Buprenorphine, a mixed central nervous system opiate agonist-antagonist, is virtually free of hallucinatory effects in parenteral formulation, the incidence being $0 \cdot 1 \% .^{\prime}$ Epidural administration of buprenorphine, however, may not be quite as free of these side effects.

\section{Case reports}

Case 1-A 40 year old woman underwent fusion of the posterior lumbar bodies at L4-5 under general anaesthetic. Postoperatively she was given $150 \mu \mathrm{g}$ buprenorphine every eight to 12 hours as needed through an epidural cannula. Forty eight hours after surgery and after a total dose of buprenorphine of $900 \mu \mathrm{g}$ she complained of nightmares (table). The symptoms occurred only at night and within 10 minutes after the drug was topped up. She was also distressed by the shadows in the room and became anxious when left alone. The symptoms disappeared once buprenorphine was stopped.

Case 2-A 38 year old woman underwent posterior spinal fusion between the transverse processes (L1-3). Postoperatively analgesia was maintained through an epidural cannula with $150 \mu \mathrm{g}$ buprenorphine every eight to 12 hours as necessary. After 48 hours she complained of a recurring dream in which she recalled a frightening incident from her past. The dream recurred so vividly at night that she became extremely distressed. She had received a total dose of $750 \mu \mathrm{g}$ 
over the two days. She was extremely anxious about being left alone, but once the analgesia was withdrawn all symptoms disappeared.

Case 3- A 58 year old woman underwent fusion of the posterior lumbar bodies with fusion of the alar transverse processes at L5-S1. On the third postoperative day the became convinced that her leg was black despite reassurances to the contrary. A total dose of buprenorphine of $1150 \mu \mathrm{g}$ had been given. When the drug was withdrawn the symptoms disappeared.

Cases 4 and 5-Two further cases occurred (table). Symptoms did not develop until the third postoperative day.

Patients with psychotomimetic symptoms after epidural buprenorphine

\begin{tabular}{|c|c|c|c|c|}
\hline $\begin{array}{l}\text { Case } \\
\text { No }\end{array}$ & $\begin{array}{l}\text { Sex and } \\
\text { age } \\
\text { (years) }\end{array}$ & Operation & $\begin{array}{l}\text { Presenting } \\
\text { hallucinatory } \\
\text { symptoms }\end{array}$ & $\begin{array}{c}\text { Total dose of } \\
\text { buprenorphine }\end{array}$ \\
\hline 1 & F 40 & $\begin{array}{l}\text { Fusion of lumbar } \\
\text { bodies posteriorly }\end{array}$ & $\begin{array}{l}\text { Saw horrifying } \\
\text { creatures in wall }\end{array}$ & $900 \mu \mathrm{g}$ \\
\hline 2 & F 38 & $\begin{array}{l}\text { Fusion of spine } \\
\text { between transverse } \\
\text { processes } \\
\text { posteriorly }\end{array}$ & $\begin{array}{l}\text { Dreamt of frightening } \\
\text { episode of her } \\
\text { youth }\end{array}$ & $750 \mu \mathrm{g}$ \\
\hline 3 & F 58 & $\begin{array}{l}\text { Fusion of lumbar } \\
\text { bodies between } \\
\text { alar transverse } \\
\text { processes }\end{array}$ & $\begin{array}{l}\text { Believed her leg to be } \\
\text { black }\end{array}$ & $1159 \mu \mathrm{g}$ \\
\hline 4 & M 42 & $\begin{array}{l}\text { Fusion of lumbar } \\
\text { bodies posteriorly } \\
\text { (L4-5) }\end{array}$ & $\begin{array}{l}\text { Thought that there } \\
\text { were people in } \\
\text { room talking about } \\
\text { him }\end{array}$ & $1000 \mu \mathrm{g}$ \\
\hline 5 & M 55 & $\begin{array}{l}\text { Repair of } \\
\text { pseudoarthrosis } \\
\text { (L3-4) }\end{array}$ & $\begin{array}{l}\text { Thought that objects } \\
\text { in room were falling } \\
\text { on top of him }\end{array}$ & $1200 \mu \mathrm{g}$ \\
\hline
\end{tabular}

\section{Comment}

Buprenorphine, with its high lipid solubility and avidity for opiate receptors, is a useful alternative to intramuscular morphine when injected into the epidural space after spinal reconstructive surgery. ${ }^{2}$
The incidence of associated psychotomimetic symptoms, however, has not been reported. We examined the records of all cases of spinal reconstructive surgery in this hospital in 1987 and 1988. One hundred patients were operated on, of whom nine exhibited some form of hallucinatory behaviour. The epidural dose prescribed in the five cases reported here was $150 \mu \mathrm{g}$ six to eight hourly as required, which is slightly less than the normal postoperative dose.

The high lipid solubility of the drug results in local action at the level of the spinal cord. The drug may act through attachment to $\beta$ enkephalin receptors as well as through the systemic circulation via the epidural venous plexus. This latter effect was probably the aetiological mechanism in the cases reported here and is supported by a report of near fatal auditory hallucinations after sublingual administration of buprenorphine. ${ }^{3}$ Though no firm evidence exists to implicate altered opiate systems in the aetiology of the affective psychoses, ${ }^{4}$ our cases provide evidence of a possible excitatory or disinhibiting effect of buprenorphine on the limbic and extrapyramidal systems, which have a role in changes in behaviour and mood induced by opiates. Whether this is caused by a direct effect on specific opiate receptors which then stimulate other arousal pathways, whether buprenorphine causes an increase in $\beta$ endorphin concentrations in the corpus striatum, or whether a hitherto unknown class of receptors that induce arousal could be a factor remains to be elucidated.

1 Harcus AH, Ward AE, Smith DW. Buprenorphine in postoperative pain results in 7500 patients. Anaesthesia 1980;33:382-6.

2 Murphy DF, MacEvilly M. Pain relief with epidural buprenorphine after spinal fusion: a comparison with intramuscular morphine. Acta Anaesthesiol Scand 1984;28:144-5.

3 Paraskeviades EC. Near fatal auditory hallucinations after buprenorphine. Br Med f 1988:296:214.

4 Thompson JW. Opioid peptides. Br Med f 1984;288:259-60.

(Accepted 16 fanuary 1989)

\section{Occupational asthma in nurses caused by chlorhexidine and alcohol aerosols}

\section{E R Waclawski, L G McAlpine, N C Thomson}

Occupational Health Service, Greater Glasgow Health Board, Glasgow E R Waclawski, MRCP, senior registrar

\section{Department of Respiratory \\ Medicine, Western \\ Infirmary, Glasgow \\ L G McAlpine, MRCP, registrar \\ N C Thomson, MD, consultant physician \\ Correspondence and requests for reprints to: Dr E R Waclawski, Occupational Health Service, Southern General Hospital, Glasgow G51.}

BrMed F 1989;298:929-30
Chlorhexidine is known to sensitise skin ${ }^{1}$ and has been associated with severe allergic reactions. ${ }^{2}$ We are not aware of any previous report of an association between asthma and the use of chlorhexidine and alcohol aerosols. We describe two cases.

\section{Case reports}

Case 1-A 54 year old nursing auxiliary presented with a three month history of increasingly frequent attacks of cough and wheezing. These episodes occurred within minutes after she used a chlorhexidine and alcohol aerosol (Dispray 2 Hard Surface Disinfectant, Stuart Pharmaceuticals, Wilmslow, Cheshire) to disinfect incubators. She had been a cigarette smoker previously but did not have a history of asthma and was not receiving treatment for asthma. Spirometric testing gave normal results, with the ratio of forced expiratory volume in one second to forced vital capacity being $3 \cdot 4: 4 \cdot 2$ litres $(81 \%)$. The concentration of histamine causing a $20 \%$ fall in the forced expiratory volume in one second was $9 \cdot 2 \mathrm{~g} / \mathrm{l}$, indicating borderline hyperresponsiveness of the airways. ${ }^{3} \mathrm{~A}$ bronchial provocation test that mimicked the woman's normal use of the aerosol was performed, during which she cleaned the work surfaces in a small ventilated laboratory with this agent for 30 minutes. Spirometric values were recorded over the next eight hours and compared with those taken over eight hours on a control day. The forced expiratory volume in one second fell by $13 \% 10$ minutes after the challenge, and this was associated with cough and chest tightness. No late response was observed.

Case 2-A 43 year old midwife presented with a six month history of chest tightness after exposure to a chlorhexidine and alcohol aerosol (Dispray 2). She was a non-smoker and did not have a history of asthma, but she had recently been prescribed a salbutamol inhaler. Spirometric tests gave normal results, with the ratio of forced expiratory volume in one second to forced vital capacity being $3 \cdot 49: 4 \cdot 05$ litres $(86 \%)$. A histamine challenge test indicated normal airways responsiveness, the concentration of histamine causing a $20 \%$ fall in the forced expiratory volume in one second being $>16 \mathrm{~g} / \mathrm{l} .^{3}$ The patient recorded peak expiratory flow rates five times daily. At work there was a $43-48 \%$ variation between maximum and minimum values compared with less than $10 \%$ variation away from work (figure). A bronchial provocation test with the aerosol showed a maximum fall in forced expiratory volume in one second of $22 \%$ two minutes after exposure to the spray. No late response was observed.

\section{Comment}

Neither of our patients had a history of asthma or increased airways responsiveness to histamine when 